\begin{tabular}{|c|c|c|}
\hline & Int.J.Curr.Microbiol.App.Sci (2021) 10(08): $441-447$ & $a=1$ \\
\hline & $\begin{array}{l}\text { International Journal of Current Microbiology and Applied Sciences } \\
\text { ISSN: 2319-7706 Volume } \mathbf{1 0} \text { Number } 08 \text { (2021) } \\
\text { Journal homepage: } \underline{\text { http://www.ijcmas.com }}\end{array}$ & $\geqslant 9 \sin \Rightarrow$ \\
\hline $\begin{array}{l}\text { EXCELLENT } \\
\text { PUBLISHERS }\end{array}$ & & unww.jicmas.com \\
\hline
\end{tabular}

Original Research Article

https://doi.org/10.20546/ijcmas.2021.1008.054

\title{
To Evaluate Business Performance of Maa Vidya Seeds and to Examine the Marketing Pattern of Maa Vidya Seeds
}

\author{
Yogesh Sahu $^{1 *}$, V. K. Choudhary ${ }^{2}$, A. K. Gauraha ${ }^{1}$, Teekendrakumar Sahu ${ }^{1}$ \\ and Rashmi Jaiswal ${ }^{1}$ \\ ${ }^{1}$ Department of Agribusiness and Rural Management, ${ }^{2}$ Department of Agriculture Economics, \\ COA, IGKV, Raipur- 492012, C.G., India \\ *Corresponding author
}

Keywords

breeders,

foundations,

certified seeds,

offspring, NSC,

SFCI, State Seed

Corporation

Article Info

Accepted:

20 July 2021

Available Online:

10 August 2021

The purpose of this study was to evaluate business performance of maavidya seeds and to examine the marketing pattern of maavidya seeds in Arang, Raipur District of Chhattisgarh. Raipur district consist of four blocks: Dharshiwa, Tilda, Arang and Abhanpur. In order to achieve the main objective of production of seeds of paddy seeds and their marketing at reasonable prices to the farmers. The study was under taken under the Maa vidya Seed Co-operatives Situated at Arang, District Raipur. Respondents were mainly the paddy grower registered under Maa vidya seeds for their production program. The major respondent's includes growers followed by traders and farmers cultivating paddy. Both primary and secondary data needed for the study were obtained by conducting a survey of households and paddy seed processors using a pre- tested question schedule. The study concluded that the majority of the growers choose graduation of as level education. The study area's main crop was paddy. Total grading costs of paddy seed was calculated at Rs. 145.72 per quintal, Gross income was calculated at Rs. 2800 per quintal, Gross expanse was calculated at Rs. 2095.72 and Net profit of certified paddy seed was Rs. 704.28 per quintal. Input-Output Ratio was 1:1.33 Distributions of paddy seed from Maa Vidya Seeds to different agencies and farmer's 50 percent seed were directly sold to the Government seed agencies, 40 percent seeds were sold to the wholesaler and remaining 10 percent of seeds were distributed to retailers. The main issue faced by the graders is quality control, High packaging cost, and bad raw material. 


\section{Introduction}

\section{Seed Production System in India}

The Indian seed production program mainly follows a limited generation system for staged seed multiplication. The system recognizes three generations, such as breeders, foundations and certified seeds, and provides sufficient guarantees of quantitative assurance throughout the seed propagation chain to maintain the purity of the variety as it passes from breeder to farmer.

\section{Breeder seed}

The offspring of various types of nuclear seeds produced by the source breeder of sponsored breeder is known as breeder seed. Seed production by breeders comes under the purview of the Indian Council of Agricultural Research (ICAR) and is done through: ICAR Research Institute, National Research Center and all Indian multi-crops coordinated research projects; State Agricultural University (SAU) with 14 centers established in various states; the sponsored breeder is recognized by states seed corporations and NGOs. ICAR is promoting a sponsored breeding seed program through National Seed Corporation (NSC) / State Seed Corporation (SSC), Krishi Vigyan Kendra (KVK), etc. Breeder seed production has steadily increased in recent years.

\section{Foundation seed}

The foundation seed is the progeny of a Breeder seed and must be obtained from Breeder seed or a foundation seed that can be clearly defined from the Breeder seed. Foundation seed produced by the NSC, SFCI, State Seed Corporation, State Agriculture Department and private seed producers with the necessary facilities. The foundation seed must undergo both field and laboratory testing to meet the seed certification standards set forth in India's minimum seed certification standards.

\section{Certified seed}

Certified seed is the progeny of foundation seed that must meet the seed certification standards outlined in the Indian minimum seeds certification standard of 1988. In the case of self-pollinated crops, certified seeds can be made from certified seeds as long as the numbers of generation from the foundation seed stage-I do not exceed three.

\section{Seed replacement rate}

It is up to the farmer to decide whether to grow certified seeds or farm saved seeds. Seed replacement rate (SSR) or seed replacement ratio is a percentage of total cropped area sown with certified seeds versus farm saved seeds.

However, because every farmer is aware of the advantages of certified seeds, he will want to sow certified seeds if he is produced with the necessary supplies of certified seed. As a result, the seed replacement Ratio refers to the actual quantity seed distributed to farmers versus the actual seed required for crop cultivation.

\section{India's Seed Replacement Rate}

India has a poor seed replacement ratio due to a large demand- supply gap. Only about 15 percent of India's total cropped area is currently planted with freshly obtained quality seed each year. A massive 85 percent of the land is sown with farm-saved seeds.

This ratio varies by crop, ranging from 7 percent in staple crop to as high as 70 percent in some vegetables and fruits. It's a safe bet for wheat and rice. 


\section{Chhattisgarh's seed replacement}

Seed replacement rate of Chhattisgarh: Rabi (unit in \%)

\section{Seed Processing}

Winnowing has been used to clean seed from man's food crops for thousands of years. This is still an important process, but it no longer provides the type of seed that farmers require.

Seed processing is an important part of seed production because it allows plant breeders to get their improved genetic materials into commercial channels, which helps feed the world's rapidly growing population. Because the farmers' entire crop depends on it, he must obtain high-quality seed that is free of all undesirable material. Seed is very seldom planted in the state in which it is received from the grower. Many seed lots, in fact, contain weed or crop seed or inert material rendering them unfit for sale unless they are processed. Crop seed often has stems, awns, clusters, and other structure that prevent it from flowing freely through the drill. Seed processing is the part of the seed industry that upgrades seed, improves seed, planting conditions, and applies chemical protections to seed.

\section{Advantage of seed processing}

Better uniformity in planting rate by proper sizing.

Prevent spread of weed seed.

Prevent crops from diseases.

Reduces seed losses by drying to proper moisture content.

Facilitates uniform and improved marketing by providing proper packaging and storage.

\section{Materials and Methods}

Out of 27 district of Chhattisgarh states, Raipur district has been selected purposively for the present study. At present Raipur district includes 4 blocks viz. 1) Dharsiwa 2) Tilda 3) Abhanpur 4) Arang. In order to achieve the main objective of production of seeds of paddy seeds and their marketing at reasonable prices to the farmers.

The study was under taken under the Maa vidya Seed Co-Operatives Situated at Arang, District Raipur. Respondents were mainly the paddy grower registered under Maa vidya seeds for their production program. The major respondents including growers followed by traders and farmer cultivating paddy.

Primary data are collected through prepared schedule on the basis of requirements of the data from paddy seed growers and seed processer for different objective in study area. Information about the registered seed growers under the seed production program, along with the class of seed, quality of seed utilized and the area covered was collected from Maa vidya Seed Co-operative.

Human labour has been input at the market wages rate prevailing in the locality. Machine labour Producers that use machine energy for various processing activity.

Interest on the fixed capital was calculated @ $7 \%$ for the per annum. Depreciation represented the amount by which a farm resources decreased in value a result of cause other than a change in the general price of the item straight line method was used for calculating the depreciation :

Purchased price of the assets-junk value

Depreciation $=\longrightarrow \times 100$

No. of useful years of life (expected life) 


\section{Secondary data}

Secondary data were collected from journals, books. As well as through interactions with various officials of the co-operatives.

\section{Input-output ratio}

It can be expressed as the ratio of total output to total input. The ratio was calculated as:

Input-output ratio

Input cost

= ------------X 100

Output cost

\section{Results and Discussion}

\section{Grading Cost}

According to table 4.7, the average grading cost for paddy was estimated to be Rs.145.72 The major cost of grading of paddy seeds was found to be 46.04 percent Packaging, 28.43 percent Labour cost, 5.41 percent transportation cost, 2.70 percent marketing and 1.35 percent milling/grading cost respectively of total grading cost.

\section{Profitability aspects of seed grading unit}

These details about gross income, gross expanse and profit of seed grading unit have been shown in table 4.8. It was observed that the gross expanse was Rs.2095.72 of sample unit. In which expanses on raw material covered 93.04 percent to gross expanses and 6.95 percent was Milling/grading cost. The average gross income was Rs. 2800 and the net profit was Rs.704.28 per quintal.

\section{To examine the marketing pattern}

With marketing in agriculture, product disposal had become an important aspect of agriculture's economy. As the implementation of fresh farm technology to increase farm output prevails these days, effective marketing is required. Moving each item from the farm to the ultimate customer plays a major part in determining the product's cost, unless marketing increases no incentives to boost output will attract the processer.

\section{Packaging of seed from maa vidya seed co- operatives}

All processed paddy seed on maa vidya seed are packed in 20000 bags $(25 \mathrm{~kg} / \mathrm{bag})$ to distribute in different areas.

\section{Distribution pattern of paddy seed from maa vidya seed}

The distribution of these paddy seeds where done by Maa Vidya Seed Co-operative to different agencies and farmers 50 percent paddy seeds were directly sold to the government seed agencies, 40 percent seeds were sold to the wholesalers and remaining 10 percent seeds were distributed to retailers.

\section{Marketing channel for paddy seed}

Channel-I: Grader-Government seed agenciesfarmers

Channel-II: Grader -wholesaler-retailersfarmers

Channel-III: Grader- retailers-farmers

Indian economy is a fueled by agriculture with $60 \%$ of the Indian population engaged directly or indirectly. Agriculture and its allied sector contribute $17 \%$ of the total GDP and provided employment to $53 \%$ of the population. Seed is the basic input for sustainable agriculture. 
Table.1 Seed replacement rate of C.G. (Kharif)

\begin{tabular}{|c|c|c|c|c|c|c|c|c|}
\hline S. No. & Crops & $\mathbf{2 0 1 2}$ & $\mathbf{2 0 1 3}$ & $\mathbf{2 0 1 4}$ & $\mathbf{2 0 1 5}$ & $\mathbf{2 0 1 6}$ & $\mathbf{2 0 1 7}$ & $\mathbf{2 0 1 8}$ \\
\hline $\mathbf{1}$ & Paddy & $\mathbf{3 6 . 3 8}$ & $\mathbf{4 0 . 2 3}$ & $\mathbf{4 3 . 3 3}$ & $\mathbf{4 4 . 2 5}$ & $\mathbf{6 7 . 8 5}$ & $\mathbf{4 8 . 0 7}$ & $\mathbf{5 0 . 0 0}$ \\
\hline $\mathbf{2}$ & Maize & 27.70 & 51.54 & 55.44 & 56.57 & 66.42 & 70.71 & 82.96 \\
\hline $\mathbf{3}$ & Arhar & 12.36 & 23.87 & 24.15 & 25.62 & 26.02 & 20.33 & 32.00 \\
\hline $\mathbf{4}$ & Urad & 9.18 & 14.29 & 16.50 & 14.18 & 15.64 & 18.14 & 21.00 \\
\hline $\mathbf{5}$ & Moong & 6.33 & 33.07 & 32.44 & 23.61 & 28.19 & 36.49 & 44.44 \\
\hline $\mathbf{6}$ & Soybean & 66.33 & 68.33 & 47.11 & 48.42 & 45.19 & 37.16 & 43.27 \\
\hline $\mathbf{7}$ & Til & 23.25 & 24.00 & 34.90 & 12.25 & 15.56 & 15.33 & 41.67 \\
\hline & Ramtil & 9.36 & 9.54 & 6.80 & 4.04 & 4.00 & 4.09 & 10.56 \\
\hline $\mathbf{8}$ & groundnut & 3.59 & 4.25 & 3.02 & 5.25 & 8.48 & 5.95 & 14.77 \\
\hline
\end{tabular}

Source: CG State Certification Agency, Raipur

Table. 2 Seed replacement rate of C.G. (Rabi)

\begin{tabular}{|c|c|c|c|c|c|c|c|c|}
\hline S. No. & Crops & $\mathbf{2 0 1 2 -}$ & $\mathbf{2 0 1 3 -}$ & $\mathbf{2 0 1 4 -}$ & $\mathbf{2 0 1 5 -}$ & $\mathbf{2 0 1 6 -}$ & $\mathbf{2 0 1 7 -}$ & $\begin{array}{c}\mathbf{2 0 1 8}- \\
\mathbf{1 9}\end{array}$ \\
\hline $\mathbf{1}$ & Wheat & 34.21 & 35.18 & 35.57 & 42.32 & 40.70 & 48.46 & 51.54 \\
\hline & Gram & 19.07 & 20.45 & 13.81 & 21.77 & 20.74 & 19.86 & 20.18 \\
\hline $\mathbf{3}$ & Pea & 4.86 & 5.39 & 7.30 & 16.47 & 13.71 & 15.71 & 16.15 \\
\hline $\mathbf{4}$ & Masoor & 5.55 & 5.68 & 2.00 & 4.85 & 14.08 & 24.45 & 35.47 \\
\hline $\mathbf{5}$ & Mustard & 25.20 & 29.93 & 30.21 & 32.00 & 32.14 & 51.09 & 36.61 \\
\hline $\mathbf{6}$ & Alsi & 0.68 & 1.42 & 1.06 & 1.67 & 1.33 & 13.88 & 3.67 \\
\hline $\mathbf{7}$ & Kusum & 14.49 & 30.44 & 42.87 & 38.89 & 33.33 & 42.00 & 37.50 \\
\hline
\end{tabular}

Source: CG State Certification Agency, Raipur

Table.3 Cost of paddy seed grading (Rs/Qt)

\begin{tabular}{|c|c|c|c|}
\hline S. No. & Particular & Amount & Percent \\
\hline $\mathbf{1 .}$ & Grading & 2.00 & 1.35 \\
\hline $\mathbf{2 .}$ & Labour & 42.00 & 28.43 \\
\hline $\mathbf{3 .}$ & Oil, lubricant, repairing & 2.00 & 1.35 \\
\hline $\mathbf{4 .}$ & Gunny bags & 68.00 & 46.04 \\
\hline $\mathbf{5 .}$ & Storage & 2.00 & 1.35 \\
\hline $\mathbf{6 .}$ & Transportation & 8.00 & 5.41 \\
\hline $\mathbf{7 .}$ & Marketing/advertising & 4.00 & 2.70 \\
\hline $\mathbf{8 .}$ & Interest on working capital & 5.12 & 4.73 \\
\hline & Total variable cost(A) & $\mathbf{1 3 3 . 1 2}$ & $\mathbf{9 1 . 4 6}$ \\
\hline $\mathbf{1 .}$ & Depreciation on building & 12.00 & 8.12 \\
\hline $\mathbf{2 .}$ & and equipment & 0.60 & 0.40 \\
\hline $\mathbf{3 .}$ & License fee & 0.00 & 0.00 \\
\hline & Interest on fixed capital & $\mathbf{1 2 . 6 0}$ & $\mathbf{8 . 5 3}$ \\
\hline & Total fixed cost(B) & $\mathbf{1 4 5 . 7 2}$ & $\mathbf{1 0 0}$ \\
\hline
\end{tabular}


Table.4 Profitability aspects of seed grading unit (Rs. /qt.)

\begin{tabular}{|c|c|c|}
\hline S. No. & Particular & Amount \\
\hline i. & Value of main product & 2700 \\
\hline ii. & Value of by product & 100 \\
\hline $\mathbf{1}$ & Gross income & $\mathbf{2 8 0 0}$ \\
\hline i. & Cost of ungraded paddy seed & 1950 \\
\hline ii. & Grading cost & 145.72 \\
\hline $\mathbf{2}$ & Gross expanse & $\mathbf{2 0 9 5 . 7 2}$ \\
\hline $\mathbf{3}$ & Net profit & $\mathbf{7 0 4 . 2 8}$ \\
\hline $\mathbf{4}$ & Input output ratio & $\mathbf{1 : 1 . 3 3}$ \\
\hline
\end{tabular}

Table.5 Packaging of seed from maa vidya seed

\begin{tabular}{|c|c|c|c|}
\hline S. No. & Particulars & Amount of seeds(qt.) & Bags(25kg/bag) \\
\hline 1 & Paddy seed & 5000 & 20000 \\
\hline
\end{tabular}

Table.6 Distribution pattern of paddy seed from maa vidya seed

\begin{tabular}{|l|c|c|c|c|}
\hline S. No. & Buyers & $\begin{array}{c}\text { No. Of Distributed } \\
\text { Bags }\end{array}$ & Quintal & Percent (\%) \\
\hline $\mathbf{1 .}$ & $\begin{array}{c}\text { Government seed } \\
\text { agencies }\end{array}$ & 10000 & 2500 & 50 \\
\hline $\mathbf{2 .}$ & Wholesalers & 8000 & 2000 & 40 \\
\hline $\mathbf{3 .}$ & Retailers & 2000 & 500 & 10 \\
\hline $\mathbf{4 .}$ & others & - & - & - \\
\hline $\mathbf{5 .}$ & Total & $\mathbf{2 0 0 0 0}$ & $\mathbf{5 0 0 0}$ & $\mathbf{1 0 0}$ \\
\hline
\end{tabular}

Seed quality has been treated as sacred, being an important factor in the improvement of agriculture and agrarian societies every farmer should have access to healthy seeds which are genetically pure with high seed vigor and good germination percentage. According to state seed corporation data 2019-20 total demand of seeds (kharif + Rabi) was10,92,550 quintal and distribution was $7,75,399$ quintal. It is directly indicate to shortage of demands.

In India Seed Replacement Ratio are 15 percent and In Chhattisgarh according to state seed certification agency data 2018 SSR for paddy 50 percent, for maize 82.96 percent, for arhar 32 percent and 43 percent for soybean.
India has a significant share 4 percent of the global market.

On an average cost of grading per quintal was estimated to be Rs. 145.72 the major cost of grading of paddy was found to be 46.04 percent Packaging, 28.43 percent labour cost, 5.41 percent transportation cost and 2.70 percent was marketing cost. Value of the main product (Graded/processed paddy seed) was Rs. 2700 per quintal and value of by product (under size) Rs. 100 per quintal. Average Gross income of graded paddy seed was Rs. 2800 and Gross expanse of grading of paddy seed was Rs. 2095.72. On an average Net profit of Graded paddy seed was Rs. 704.28 and Input-Output ratio was 1:1.33 The 
producers are registered members under Maa Vidya Seed and total produced by the producers was directly sold to Maa Vidya Seeds which are processed and distributed to different agencies. On an average annual turnover of Maa Vidya Seeds is 5000 quintal per year. All processed paddy seed on Maa Vidya Seed are packed in 20000 bags $(25 \mathrm{~kg} / \mathrm{bag})$ to distribute in different area. Distribution of paddy seeds where donr by Maa Vidya Sees to different agencies and farmers, 50 percent seeds were directly sold to the government seed agencies, 40 percent seeds were sold to the wholesalers and reaming 10 percent seeds were distributed to retailers or outlate.

\section{References}

Radha, Y. and Chowdry, K. R. (2001)." Present status and policy perspectives of seed industry: A case study of Andhra Pradesh". Indian Journal of Agricultural Economics. 57(3): 481482.

Deepana, H. D., Girish, M. R. (2016). "Structure and conduct of paddy seeds market - A study in Mandya district of Karnataka state". International Research. Journal of Agriculture Economics. \& Statistics, 7 (2) : 251256,
Doi : 10.15740/HAS/IRJAES/7.2/251256.

Mula Gobinda, Layek Nityananda, Roy Bidhan, (2019),'Economics of Rice Seed Production and Marketing - A Study in Terai Zone of West Bengal, India", International Journal of Current Microbiology and Applied Sciences 8(12): 439-453.

Singh Harbir, Mathur Prasoon and Pal Suresh (2008) Indian Seed System Development: Policy and Institutional Options. Agricultural Economics Research ReviewVol. 21 January-June 2008 pp 20-29

Koundinya A. V., Kumar P. P. (2014) Indian vegetable seeds industry: status and challenges. The International Journal of Plant, Animal and Environmental Sciences.

Kumar Amit, Singh Sabita, Kumar Teshu And Jawla Subhash Kumar (2014) Market Potential and Promotional Strategy for Akshay Seed Tech Co. in Sabarkantha and Gandhinagar Districts. Annals of Agri-Bio Research 19 (4) : 757-762, 2014

Nandi A. K., Das B., Sable M. (2013) Production and marketing strategy of seeds for developing countries. Business Journal of Crop and Weed.

\section{How to cite this article:}

Yogesh sahu, V. K. Choudhary, A. K. Gauraha, Teekendrakumar sahu and Rashmi Jaiswal. 2021. To Evaluate Business Performance of Maa Vidya Seeds and To Examine the Marketing Pattern of Maa Vidya Seeds. Int.J.Curr.Microbiol.App.Sci. 10(08): 441-447. doi: https://doi.org/10.20546/ijcmas.2021.1008.054 